\title{
Teaching Tactics in Business Schools: A Comparative Viewpoint on Motivation \& Leadership Contexts
}

\author{
Nadir Kolachi ${ }^{1}$ \\ ${ }^{1}$ Skyline University, University City of Sharjah, UAE \\ Correspondence: Nadir Kolachi, Skyline University, UAE. Tel: 971-56-264-2546. E-mail: \\ nadir.kolachi@gmail.com
}

Received: May 23, 2015

Accepted: July 13, 2015

Online Published: July 22, 2015

doi:10.5539/ijbm.v10n8p88

URL: http://dx.doi.org/10.5539/ijbm.v10n8p88

\begin{abstract}
The concept of genius leadership is to lead organization through maintaining ethical standards that covers corporate social responsibility, accountability, employee motivation, employee development and instilling loyalty in particular. Good business schools teach enough to equip the students with the knowledge to be applied on the companies. Bad business schools teach less and require other certifications to know what they can contribute to the organization. Business Schools are the best platform to train students for innovating new businesses and help organizations to manage corporate affairs in most effective manner. Good business schools teach to set goals and bad business schools teach to spoil the set goals. This research is basic in nature and has proposed two models based on the motivation \& leadership themes. The first relates to individual perspective and the second is about an organizational perspective. Both the models explain the response of emerging business schools if they follow and apply in order to learn how to set goals at individual \& organizational levels.
\end{abstract}

Keywords: motivation, leadership, management education \& business schools

\section{Introduction}

The world is replete with hundreds of business schools but only few can provide the quality education and the rest are just schools with business. The good business schools provide quality education but schools with business provide degree with less quality education. The huge gap has already been explored to some extent but has not yet been filled. This research will report on the strength of business schools with the right curriculum in management sciences and attach the practical based motivation \& leadership models as proposed in this research The purpose of proposing the models at individual \& organizational levels is to help business schools to teach how to set goals? The models will also facilitate students to understand the tactics of setting goals. Good business schools consider students as the products and sell to companies with high valued prices. Bad business schools consider students as customers and throw them to companies at any price available. A great concern is to motivate students to work, innovate, enhance capability, learn competency and adopt changing forms of professionalism as required by the modern corporations. The changing forms of professionalism are the agility to work, interest in company, ability to listen, influence to employees and play a role of helping hand for the colleagues and company at whole. Business schools have contributed a significant role in the society. Good business schools invest in faculty research, provide due support and appreciate those who make students to graduate with innovative ideas. The role has also been very significant in professional development of students. This age has provided huge data on management curriculum but motivation and leadership still needs to be specific for business management students. Two propositions are mentioned in this research, first is about process of motivation at individual level that will explain various important factors through easiest way as $\mathrm{A}$ to $\mathrm{Z}$ parameters and second is relevant to motivational model with reference to leadership approach at organizational level. This will elaborate the role of HR towards spreading motivational parameters to achieve organizational objectives. Both models are also discussed with upwards down \& downward up arrows at individual and organizational levels.

\section{Literature Review}

Good motivation \& tactical leadership maintains discipline \& relationship. The only source of initiating corporate reputation is the desired relationship between employer \& employees. Discipline and disciplinary rules have long been recognized to be key dimensions of the employment relationship (Edwards, 2005). HR is aware 
of changing trends and keeps employees informed about all policies. Learning increases human capital (Lazear, 1998), therefore organizations have to engage their workers in training and development because of the rapidly changing working environment (Wild, Griggs, \& Downing, 2002; Beaver \& Hutchings, 2005; Ong \& Lai, 2006; Griffin, 2011). Business schools are required to teach students the prevailing \& innovative quality management systems. This helps HR managers to lead employees toward required efforts for the company. Leadership influences employees to be motivated with good management system. This makes employees competitive and helps organization to overcome many problems. The Quality Management System suggests that employees behave in a sense of responsibility and perform their actions by themselves without being mentioned to them about necessary works to be done (Türkel, 1998, p. 41). The quality management system seems to have a key role for applications of human resources management (Kline, 2002, p. 73). HRM should overcome problems confronted with the expanding of the field related to human, work in new competitive atmosphere (Hansen, 2002, p. 516). Students must be given a sense of high recruitment in the company. The performance is always increased if taught in good manner. Recruiting consists of attracting new people to the company, and selection consists of choosing the right people (Dessler, 2003, p. 106). Performance evaluation is a formalized process for classifying the employee's current performance (Stoner \& Freeman, 1999), Business schools must be clear to set goals for faculty and faculty keep those goals forward to students. Good schools coordinate with faculty to set required goals. Organizational learning is important while working in the organization. Business schools teach motivation \& leadership models with reference to organizational learning to be effective during studies. Students will be ready with more effective learning while in the organization. Heavy load of various curriculums to be completed will not result good curriculum on motivation \& leadership. Organizational learning refers to the process of improving organizational behaviors by acquiring and developing new knowledge \& capabilities (Fiol \& Lyles, 1985). Knowledge is also continuous (March \& Olsen), 1976. Heavy teaching load, community based research and many other responsibilities do result in stress (Fuhrmann, 1994; Goodwill, 1970; Spaights, 1980). Good communication \& open communication of business schools to faculty, students and academic heads is the best source of coordination to focus on management curriculum. This makes good coordination to pace up with modern \& demanded curriculum as proposed in this research. Universities are considered best places that make leaders and hone up further skills of born leaders in this world. Open communication has long been considered as important element in faculty culture (Austin, 1990; Millet, 1962). It facilitates the creation of a congenial and sympathetic company of scholars in which friendships, good conversation and mutual aid can flourish (Bowen \& Schuster, 1986, p. 55). Conversely, where communication is constrained, faculty may feel isolated from colleagues \& alienated from their work. (Linholm, 2003; Tierney Bensimon, 1996). Universities are primary places of education, research and creation of new knowledge and are crucial actors in the innovation of knowledge based societies and promotion of economic development, in synergy with institutions \& industries (Etzkowitz, 2004). Business schools require the proposed models to build \& maintain intellectual capital. The distinction features of the new University raise the problem of identifying proper frameworks for analyzing success and performance, particularly in terms of intangible and knowledge assets generated. In the 90s many conceptualizations of intellectual capital have been proposed (Bontis, 2002; Bontis, 2001; Bontis, 1998; Edvisson \& Malon, 1997; Kaplan \& Norton, 2004; Klien \& Prusak, 1994; Seemann et al., 2000). But in 2020, business schools will focus further on motivation \& leadership reforms and innovate a technique to transfer same to students.

\section{Process of Motivation (Individual Perspective)}

Following are the sequential factors of motivation that are termed as process of motivation based on individual perspective. This process can increase the commitment of Employees in the organizations. Some employees can be taught the commitment but some possess natural motivation level to be sincere with the company. Organizations motivate employees with the offers of promotion, recognition, good environment, good salaries, bonuses and other benefits. Generally, motivation is the process of accepting the demands of the employees while technically, it is a process of making them to work as desired by the he company. Such things require a strategic direction and crucial role of HR managers who drive employees as they have been manned for the organization only. Motivation is not only offering something form the company but identifying something within the employee and helping employees to achieve it as the leadership, spark, efficiency, knowledge and work style in particular. The prime requisite to motivation process is the prime interest of HR managers to do so. Modern age motivation process is not based on the life cycle hierarchies of motivation but career and leadership based as proposed in the models based on individuals \& organizational perspectives.

\section{- Ability, Bold \& Collaboration.}

- $\quad$ Fair-feeling, Goal setting \& Honesty. 
- Kind, Loyal \& Opportunistic.

- Positive, Responsible \& Social.

- Unfailing, Valor \& Worried.

Table 1. Motivation \& Leadership (individual level)

\begin{tabular}{ll}
\hline 1 & Ability, Bold \& Collaboration \\
\hline 2 & Fair-feeling, Goal setting \& Honesty \\
3 & Kind, Loyal \& Opportunistic \\
4 & Positive, Responsible \& Social \\
5 & Unfailing, Valor \& Worried \\
\hline
\end{tabular}

Ability is one of the first and foremost tools of motivation, capable people always want to do something in the company, they want to contribute and their ability will push them to find something to put efforts. Organizations need to hire people with highest ability and skills so that they can make a difference in the company for example: if somebody is drowning in the water and you are out of the water. If you know swimming you will jump into the water to save the person, this means your ability to swim made you to jump, in the similar way if you are capable enough you have skills, and you will definitely do that. The second is bold which should be with every manager especially at higher levels. Managers need to take some bold steps. If any top level employee is bold then he or she will not wait to waste time but will take bold but calculated decisions. Boldness in decision making or in risk taking, it has always been an effective motivational tool, For example if someone keep avoiding the problem the problem will keep following you but if you stay and face the problem, it will go away. The next is collaboration which helps employee creating cordial atmosphere. It remained motivational tool as it helps employees to know and interact with one another. Such things will always help employees to understand company and put more efforts to achieve organizational goals. For example: some time one cannot do everything in the organization and he/she needs some help from others at that time, collaboration process helps get things in the right direction. The next one is very important which is based on being fair feeling. Fair behavior always motivates you to become fair feeling naturally. Fair feeling people always consider others fair and promote positive attitude in all regards. This is also concerned with the next point goal and honesty. Fair feeling attitude will motivate employees to put sincere efforts to achieve desired goals. Fair feeling people are goal oriented, honest and never let any vicious to come in them and company in particular. The next term is very simple and similar. The kindness is natural motivation to take initiative to help and work honestly. The next is loyal. The loyalty will always pay something good to the company. The next is opportunity which is a great thing and when people get it they always want to avail it. In this way, if employees are given good task and opportunity, they will deliver hundred percent which will give ultimate help to company. A very common saying that Talent without opportunity is nothing, so if employees have little bit talent or what extent, they must be given a chance to show what they can do. The next is positive. An employee or any individual can only be successful when somebody has positive thoughts and such thoughts will make an employee focus on the job rather than on any trivial issue. The next two steps are very common as responsibility and social. Responsibility is no doubt, a great motivational tool and complete organizational task on time and being social is very important as well because it creates very cordial atmosphere. Employees must be unfailing as it is next term in this process of motivation. Unfailing employees always have leadership and growth wish to perform the tasks. The next is valor and worried. First is explaining the concern of doing something good, the second is being cautious not to repeat the previous mistakes.

\section{Motivation \& Leadership (Organizational Perspective)}

This model reports on HR leadership that adopts the basic approach to motivate employees for the betterment of the company. The model comprises on three main aspects as HR leadership that is related to management \& employee development. HR plays a role in employee development through HRD processes and corporate trainings as planned by the company. The second aspect is the motivation that comprises on further sub-headings as input, process \& output. This is the basic approach for organizational perspective based on the factors mentioned in sub categories. The third one is about organizational leadership that explains organizational management through good corporate plans \& development. 
Table 2. Motivation \& Leadership (organizational level)

\begin{tabular}{llll}
\hline HR Leadership & Employee Management \& Development & \\
& Inputs & Process & Output \\
& Efficiency & & \\
Motivation \& Leadership & Exposure & Sense of ownership \& work & Results \\
& Experience & Sense of Caring \& spark & \\
& Efforts & & \\
Organizational Leadership & Organizational Management \& Development & \\
\hline
\end{tabular}

In the above process, employees are evaluated on the basis of inputs (achievements) and outputs (results). If employees enthusiastically possess and work on the inputs, it can bring very productive results and rewards. Additionally, this is only possible when organization work to develop intellectual capability of employees, organizations must work to make both (input) and (output) happen through instilling employees with process (sense of ownership, sense of working, sense of caring and spark).

\subsection{Input}

Employees having efficiency can make a difference in achieving results in a very quick process. Employees having much experience can never repeat previous mistakes. Employees having enthusiasm to put efforts can achieve all tasks. The companies' contribution to achieve all in input can be possible through providing a facilitative platform to make employees use utmost efficiency to achieve targets. Companies must convince employees to take different tasks and responsibilities as to enhance more exposure of the required domain. Companies provide employees a chance to participate, encourage to apply different techniques and wrestle with different tactics to get much experience which will get company good results. Company must provide good and rewarding rewards as employees keep putting efforts for the betterment of the company.

\subsection{Process}

Employees having sense of ownership with the company can always think about the company. Sense of ownership create much inspiration, sense of working and sense of caring. Employees having sense of ownership can always work, think, care, promote and remain attached with its achievements. Employees having spark, sense of doing something very special, ambitious driven approach and will move company towards right direction. Employees need a training of reminding employees to wake their spark and keep it always alive. This process can be achieved through leadership which is specifically inclined to build trust and develop employees through creating sense of ownership among employees. This is kind of culture which is to be worked at the larger scale.

\subsection{Output}

The last point in this process is Output which is mostly result based. After applying input, follow proper process, the output is always much awaited and interestingly employees wait for its feedback. If company achieved the required result, it is very good otherwise employees take initiatives to work more on it. Purposefully, the review is done in order to achieve what was secret of success or what went wrong if results not achieved? The review study will also help to find the reliability of the input and process and in the end results are evaluated to check the yardstick what would be done next. The last one will be applied on the basis of good achievement, then rewards will be given to motivate more as good and improved process next time.

\section{Analysis and Discussion}

This research is based on the qualitative approach that has generated the motivational processes that are modern and easily applicable on the organizations. Through this analysis, the research explained that motivational processes are much better than old motivational models generated few decades back. Modern professionals of modern companies require such proposed motivational processes that are mentioned in the qualitative study. Today's professionals are required to do all good things, improve productivity, build employees, enhance employee efficiency, work on the intellectual capital and get competitive models adopted by employees. This is possible through any sequential steps as mentioned in the motivation processes (individual \& organizational perspective) outlined in this study. Following is the basic approach of teaching \& applying proposed models at business schools. Business schools can play very important role to spawn geniuses of the proposed models that are properly applied and understood. Following is the proposed construction of instruction for business schools. 


\subsection{Method of Instruction to Construct the Proposed Model (Individual Level)}

This process should be taught with the practical examples and requirements of each point mentioned from A to Z. Business schools can make students grasp more if each point is discussed \& explained the way it is in the organization and how leaders, managers \& individual have practiced it. Each point must be related with the story happened with someone in any organization? This is possible through the plan, competition of students, and inspiration of teachers \& experience of guest speakers that will create good learning environment at schools. This can also be done through meetings and teamwork. People with great ability and intention to do something for the company will take initiative to speak in the meeting and suggest good things by offering himself/herself as volunteer if required. Soft skills are the best source in collaboration with company. People with collaborative skills are always taking bold steps and show responsible behavior to accept company tasks. Some business schools only teach the term but they must teach the term with story, application, experience, mini case discussions and take input on the term. This can make a huge impact and will remain as a great salutary effect on the students. This model can best be taught through examples of situations where each parameter fits and gets flow with another one that is next in the model. Following up the situation, some people who got success with the parameters application may also be discussed with reasonable examples. All successful people or corporate leaders might have done something that relates to the parameters mentioned in the model. This can be done through the experience, autobiography, some good material in books and inspirational leaders who led company to great success. This process may take some time to explain each point in detail.

\subsection{Method of Instruction to Construct the Proposed Model (Organizational Level)}

Business schools are advised to initiate following sequential construction to teach models and include in the management curriculum with special reference to Management, HRM and Leadership courses.

\subsubsection{Role of Teacher}

Teachers' role is very crucial as always but some contents demand different tactics that may keep students motivated. The tactics of following case studies, showing videos, maintaining interaction and dialogue based sessions are always considered very effective at business schools. The point of concern is that it is not maintained every time at all schools that offers business education. The role of a teacher in this particular instruction regarding model is based on the interest, expression and research work. Teacher needs to be clear of all parameters mentioned in this model. Teacher must show high interest in determining the relevant concepts. Teacher should explain about each point mentioned in this model. Teacher must pick each point and relate with any relevant corporate story and list the successes \& failures that happened in the corporation. This experience will give students a spark of learning something very special and then may decide to cope up with such situations.

\subsubsection{Role of a Student}

Students' role is equally important for learning the model. Students who are geared to adopt some teaching methods are successfully grasp the concepts. Students are always at receptive side but can be better if they have been guided to do little homework before the discussion as happened at many business schools. Students need to explore the concepts and find relevant stories about the parameters mentioned in the model. They must collect real cases, relate cases, make stories, and conceptualize the concepts to exchange with others.

\subsubsection{Theory Based Concepts}

Student must be taught the basic concepts regarding the contents of the model.

\subsubsection{Practical Based (Successful People)}

Students should be facilitated with guest speakers' session of only most successful people to grasp the relevant concepts.

\subsubsection{Case Based (Developing Situations)}

Students \& Teachers should develop case based solution to practice and enhance capability of understanding cases.

\subsubsection{Role of Both Teacher \& Student}

This makes both the parties to discuss the parameters of this model. They need to justify the points with stories relevant to points. They need to exchange the ideas on such concepts to be ready to make decision and explain new models to solve situations. 


\subsubsection{Teaching by Way of Comparative Analysis}

This method is covered by both parties. Students \& teachers will explore the comparative concepts related to stories, experience and research work done by both parties. The best way to prepare some comparative analysis, comparative tables of relevant concepts, stories, experience and research work done on each parameter mentioned in the model. This way might be little lengthy but can have accurate application and salutary effect on students' learning \& motivation.

\subsubsection{Teaching Models by Way of Case Analysis \& Application}

This is also very important when teacher develops mini cases to help students with the concepts given in the model. Teachers teach students to solve mini cases and asked them to develop the same to hone up their analytical skills. This is only possible when both parties have some good exposure. Business schools are required to help faculty to have such exposure by faculty training, facilities in research, encouragement and good salary as performance based scenarios. This motivates faculty to produce geniuses.

\subsubsection{Teaching Models by Way of Conducting Mini Seminars \& Class Workshops}

This have been considered as the most effective method at business schools. This must not be missed at any cost. This model can be well informed to guest speakers, students, teacher and other attendees. Everyone will come with good exposure and learning will be highly achieved as most of the case is familiar to all of them. Models must be provided to guest speakers well in advance. By using the proposed models as the basis for management curriculum to be good in business schools. The model can be taught through mini cases and class workshops. This needs to be well organized as major parameters should be covered. This is the best suitable for management, HR and leadership classes in particular.

\section{Case Study Findings and Recommendations}

Following are the prime requisite characteristics of good business schools that can spawn responsible leadership. The characteristics are innovated on the basis of author's interest, experience, literature, visits and research evaluation of some selected business schools.

- Good business schools should invest time and money on both faculty \& students to teach motivation \& leadership in most effective ways. Good business schools facilitate students \& faculty with modern research tools and research aspiration through social \& technological means. They innovate practical methods of instilling motivation \& leadership in students. Good business schools do not burden faculty with administrative \& clerical stuff but project them with required motivation \& leadership. Good business schools consider faculty as the most important icon on the institute's desktop. This enhances motivation and builds their leadership approach.

- Good business schools have heads, directors, deans who are very cautious in dealing with faculty and understand the sensitivity of all the professors. This shows the value $\&$ importance of any faculty at any school. They show motivation \& leadership at all levels.

- Good business schools have routine FDP on motivation \& leadership.

- Good business schools make sure that faculty has required exposure to teach at different BBA \& MBA levels especially with the approach of motivation \& leadership.

- Good business schools comply with the faculty exposure based on the academic \& corporate leadership. The experience of both the domains can best deliver to spawn genius leadership.

- Good business schools have huge pool of exchange programs for students \& faculty to cater the need of understanding varied curriculum at schools. This is essential for producing good leaders in spite of varied mix of different cultures. This can help in understanding the approach of applying motivation \& leadership at different cultural contexts.

- Good business schools have recognized accreditation to quality associations and remain active to maintain it for longer time. The accreditation like AACSB and some other recognized by top associations. This is the tool that pushes business schools to comply quality standards.

- Good business schools have good research pool based on A category journals with special reference to high impact factor (ISI indexed \& Harzig listing)

- Good business schools maintain best management curriculum and keep it updated as per the changes in management \& technological trends. The proposed motivational \& leadership model is the new trend for business schools.

- Good business schools can maintain their success if they consider all above points and include the proposed 
models at individual \& organizational levels. The models will enhance the capability of students and make good contribution of business schools in this age of modern business \& management education.

Above characteristics can make business schools accountable to spawn genius, responsible leadership and good followership in modern companies. The proposed models are the basis for motivation and leadership that helps schools to equip students and guide corporations to adopt new things. This research doesn't consider any business school as good business school if above characteristics are not followed. There are many business schools that are good and comply with above characteristics but still few are available that operate as schools with just business and have not achieved above required characteristics

\section{Research Methodology}

The research is qualitative case study based on the observation, primary sources and author's priori interest in the field. The case based approach was considered the most suitable methodology because of the nature \& contents of the research. The purpose was to propose the models (individual \& organizational) to spawn genius leadership.

\section{Conclusion}

This has a strong recommendation for professional \& HR managers to utilize both motivational processes. The study concludes that young professionals can be best trained through the motivational processes described in the research. The main conclusion of this research is to produce leaders \& spawn geniuses through proposed models. The proposed models are basic approaches to achieve such objectives.

\section{References}

Austin, A. (2002). Preparing the next generation of faculty. Journal of Higher Education, 73(1). http://dx.doi.org/10.1353/jhe.2002.0001

Bontis N. (1998). Intellectual Capital, Management Decisions, 36, 63-76. http://dx.doi.org/10.1108/00251749810204142

Bontis N. (2001). Assessing knowledge assets. International Journal of Mgt. Review, 41-60. http://dx.doi.org/10.1111/1468-2370.00053

Bowen, H., \& Schuster. (1986). American professors, A national resource imperiled. New York.

Edvisson, \& Malone. (1997). Harper Business. New York, NY.

Edwards, P. (2005). Discipline and attendance, A murky aspect of people management. Managing Human Resources, Personnel Mgt. in transition (4th ed., pp. 376-397).

Etzkowitz, H. (2004). International Journal of Technology \& Globalization, 1(1), 64-77. http://dx.doi.org/10.1504/IJTG.2004.004551

Fiol, C. L. (1985). Organizational Learning. Academy of Mgt. Review, 10, 803-813.

Fuhrmann B. (1994). Leadership issues for faculty, Metropolitan Universities (pp. 71-77).

Hansen, W. L. (2002). Developing New Proficiencies for Human Resource and Industrial Relations Professionals. Human Resource Management Review, 12, 513-538. http://dx.doi.org/10.1016/S1053-4822(02)00075-X

Kaplan, \& Norton. (2004). Harvard Business Review, 52-63.

Klien, \& Prusak. (1994). Working paper. Center for Business innovation NY.

Kline, J. J. (2002). The Development of Human Resources Management in Quality Award Winnings Governments. Journal of Organizational Excellence, 21(4), 71-80. http://dx.doi.org/10.1002/npr.10045

Linholm, J. (2003). Perceived organizational fit, nurturing the minds, hearts \& personal ambitions of university faculty. Review of Higher Education, 125-149. http://dx.doi.org/10.1353/rhe.2003.0040

Luthans, F. (1998). Organizational Behavior (8th ed.). Boston: Irwin McGraw-Hill.

Millet, J. (1962). The Academic community. New York: McGraw Hill.

TÜRKEL, A. (1998). İşletme Yöneticileri İçin Toplam Kalite Yönetimi ve İnsan Kaynakları. İstanbul: Türkmen Kitabevi.

Wild, R. H., Griggs, K. A., \& Downing, T. (2002). A framework for e-learning as a tool for knowledge

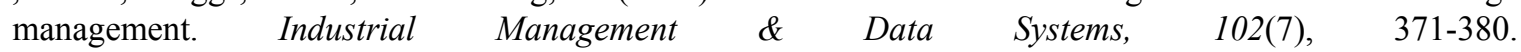
http://dx.doi.org/10.1108/02635570210439463 


\section{Copyrights}

Copyright for this article is retained by the author(s), with first publication rights granted to the journal.

This is an open-access article distributed under the terms and conditions of the Creative Commons Attribution license (http://creativecommons.org/licenses/by/3.0/). 